\title{
DECONSTRUCTION - UNSETTLING PEACE IN LEEUWENDALERS (1647)
}

\author{
Stefan van der Lecq
}

From an international perspective, early modern Dutch studies inevitably appears to be a fairly traditional and, one might argue, even staunchly conservative discipline. Whereas the likes of Shakespeare and Milton have been extensively studied from a wide range of modern theoretical perspectives, the literary figureheads of the Dutch Golden Age are still firmly ensconced in the paradigmatic frameworks of classical philology and positivist historicism. As Jürgen Pieters has recently argued, Dutch literary historians have a propensity to meet 'poststructuralist' theory either with indifference or with marked hostility. ${ }^{1}$ Their most fervent objection to incorporating the thinking of theorists such as Foucault, Althusser, Derrida, or Deleuze into the study of historical literature is that this would yield ahistorical analyses: instead of being concerned with reconstructing the function of a particular play, poem, or treatise in the context in which it was created, such analyses would wrest the text from history in order to transform it into a vehicle for the ventriloquisation of modern concerns. Marijke Spies, for example, describes the distinction between the two approaches as one between historical research and interpretation per se. ${ }^{2}$ Her choice of words is significant, implying as it does a host of further binary oppositions:

\footnotetext{
${ }^{1}$ See Pieters, 'New Historicism Revisited', p. 48. There are, however, a few notable exceptions to the general tendency towards the so-called 'Old Historicism' in early modern Dutch studies. Apart from Frans-Willem Korsten, whose work will be discussed below, Pieters names two other scholars who have attempted to introduce insights from such diverse fields as semiotics, gender studies, and deconstruction into the debates on early modern Dutch literature: Lia van Gemert and Arie Gelderblom. See Van Gemert's inaugural lecture (Norse negers) and Gelderblom's book Mannen en maagden in Hollands tuin. The article was taken up in Pieters's Historische Letterkunde vandaag en morgen.

2 Spies, 'Vondel in veelvoud', p. 239. For a thorough evaluation of Spies's position and approach, and the importance and influence of that approach in the Low Countries, in relation to international methodological and theoretical debates and developments, see Pieters, Historische letterkunde, pp. 19-92.
} 
objectivism versus subjectivism, factuality versus conjecture, representativity versus particularism, a focus on authorial intention versus an interest in the modern critic's response to the text, and so on. Spies's rigid demarcation of what counts as valid historical research within literary departments leaves no doubt as to her opinion of theories that would question the very possibility of such impartial positivism.

The fact that the rigorous battle lines which Spies drew in 1987 are largely still adhered to within Dutch departments proves the tenacity of the discipline's 'resistance to theory.' ${ }^{3}$ The reactions to Frans-Willem Korsten's recent book Vondel belicht (Sovereignty as Inviolability), in which the author makes use of the work of both early modern and post-modern thinkers in order to analyse the concept of sovereignty in the plays of Joost van den Vondel, serve as a good case in point. Riet Schenkeveld and Marijke Meijer Drees, for instance, both begin their reviews by indicating that Korsten is no specialist in seventeenth-century literature. This rhetorical disqualification of the author is followed by a litany of methodological objections that is as defensive as it is unsurprising. Korsten is accused of slapdash eclecticism, presentism, and a perverse neglect of the time-honoured criteria of the properly historical method: representativity, linear chronology, and systematic contextualisation. ${ }^{4}$ Without critically examining the traditional historicist practice that inspires their own counterarguments, both reviewers adamantly deny the merit of Korsten's modern theoretical approach to historical literature.

Rather than simply taking sides in this rather old debate, ${ }^{5}$ my contribution to the present volume is an attempt to blur the apparently

${ }^{3}$ I am alluding to Paul de Man's essay of the same name.

${ }^{4}$ See Riet Schenkeveld, 'Vondel geïnterpreteerd' and Marijke Meijer Drees, 'Nomadische voorstellingen'. Meijer Drees does discuss Deleuzian philosophy, but refuses to take Deleuze's far-reaching challenge to the historicist paradigm seriously and dismisses his thinking as an incentive to artistic creativity (p. 180-82). Schenkeveld, on the other hand, does offer one interesting point of critique next to her more conventional objections: despite Korsten's explicit intention to show the fundamental dialogism of Vondel's plays, his own book eventually amounts to a monologue (Vondel belicht, p. 140 et passim; Sovereignty as Inviolability, p. 140 et passim). I will come back to this profoundly theoretical argument below.

${ }^{5}$ Pieters traces the debate back to the two research paradigms distinguished by German philosopher Wilhelm Dilthey: positivism and hermeneutics ('New Historicism Revisited', pp. 55-56). Within an Anglo-Saxon context, however, the debate is also reminiscent of the fierce disputes in the early 1980s, when Steven Knapp and Walter Benn Michaels denied the possibility of 'doing' literary theory altogether. In their wellknown essay 'Against Theory', they argued that (textual) meaning and (authorial) 
impermeable boundary between 'historicist philology' on the one hand and 'poststructuralist theory' on the other. Can the traditional humanist critic, if he fully accepts the consequences of his practice, avoid searching epistemological questions? And can reading practices based in contemporary theory only result in historically untenable interpretations? To answer these questions I will take a closer look at deconstruction, a critical approach that many would consider to be the single most ruinous chimera of literary theory. In order to test its productivity when it comes to early modern Dutch literature, this approach will be confronted with a play that explicitly asserts its own lightheartedness: Vondel's pastoral comedy Leeuwendalers (Inhabitants of Leeuwendaal).

One of the crucial insights of deconstruction, a term coined by French philosopher Jacques Derrida in the late 1960s and propagated in the English-speaking world by the so-called Yale school of criticism, is its challenge to the assumption that language can be used to convey lucidly a determinate meaning. Derrida uses the term différance - the infinite process of signification, which amounts to a movement that unstoppably progresses along a chain of different signifiers and continually defers the production of ultimate sense - to demonstrate why linguistic utterances can in principle never acquire a 'true' meaning. The illusion of such an absolute meaning can only be sustained when the alternatives that inevitably present themselves are pushed away, suppressed, or radically excluded. In Western thought, a prevalent strategy to establish 'meaning' has been to set up structures of binary oppositions: male versus female, speech versus writing, nature versus culture, and so on. The terms of these oppositions are often ordered hierarchically and aspire to a status of transcendental or universal validity. In his writings, Derrida characteristically proceeds to read a (philosophical) text in order to expose where it unwittingly shows traces of alternative meanings that directly contradict what it purports to argue. ${ }^{6}$

In adapting Derrida's thinking for literary criticism, the first generation of deconstructionist critics has made heavy use of the New

intention are falsely treated as separate terms by contemporary theorists. The empirical difficulties of such an enterprise notwithstanding, Knapp and Michaels claimed that the proper task of literary criticism is simply to ascertain the author's intention through his writing. For their essay and the wide range of replies from the field they sought to abolish, see Mitchell, Against Theory.

${ }^{6}$ My summary overview of Derrida's work is based on Jonathan Culler's insightful discussion in On Deconstruction. 
Criticism's practice of close reading. By meticulously uncovering that which a text must not say in order to constitute a meaningful whole, early Derrida enthusiasts such as Paul de Man and J. Hillis Miller have demonstrated how the struggle between conflicting forces within a text unfailingly ends in aporia: the reader is faced with a tangle of antithetical alternatives that logic cannot dissolve. To see how such a reading tactic might be productive, the work of Barbara Johnson, a onetime student of De Man's, is extremely helpful. In The Critical Difference, she succinctly defines deconstruction as 'an attempt to follow the subtle, powerful effects of differences already at work within the illusion of a binary opposition.7 According to Johnson, binary oppositions are illusory because they rely on the repression of internal difference: difference between entities is often an outward projection of difference within entities. To read a text deconstructively is to trace the intricate ways in which it represses its self-difference in order to appear homogeneous, stable, and whole. Rather than seeing difference as a reliable method of discrimination, Johnson claims it is a textual unknown that works to produce meaning. As she puts it in A World of Difference, a deconstructive reading sets itself up for an encounter with the surprise of otherness, which is 'that moment when a new form of ignorance is suddenly activated as an imperative. 8

Deconstruction has been accused of being a largely apolitical practice, and this may be one of the reasons why the works of Jacques Rancière and Giorgio Agamben have become more and more important in the Americas at present - or the works of Antonio Negri and Michael Hardt, for that matter. ${ }^{9}$ Terry Eagleton, for instance, with his highly political, Marxist background, describes Anglo-American deconstructive criticism as 'blank ammunition' that affirms nothing and Jacques Derrida's own work as 'grossly unhistorical, politically evasive and in practice oblivious to language as "discourse" ${ }^{10}$ Richard Beardsworth, on the other hand, reads Derrida more subtly and describes the experience of aporia, the moment when reason fails in the face of undecidability, as the very condition of decision and action (Derrida \& the Political). If approached from this angle, deconstruction

${ }^{7}$ Johnson, The Critical Difference, p. xi.

${ }^{8}$ Johnson, A World of Difference, p. 16.

9 Especially Rancière, The Politics of Aesthetics; or Giorgio Agamben with his State of Exception and Means Without Ends. Recently Negri and Hardt have been influential with their studies Empire, Multitude, and Commonwealth, respectively.

${ }^{10}$ Eagleton, Literary Theory, pp. 147-48. 
becomes an inherently political process: it shows any meaning with a claim to finality to be a provisional decision founded on ideology rather than a firmly grounded truth based on logic or reason. With respect to this, it is not so much that there is a rift in the history of poststructuralist thought in the US, between, say, on the one hand Foucault and Derrida, and on the other Rancière, Agamben, Negri and Hardt. Rather there are decisive nodes and connections in the work of all these.

It is precisely the political potential of deconstruction that makes it a relevant theoretical framework for a reading of Leeuwendalers. Since the play is a self-proclaimed celebration of peace, the deeply political questions it touches upon have often gone unnoticed. In my analysis, I will seek to activate the 'otherness' embedded in the seemingly familiar and uncomplicated concept of peace. I propose, in other words, to pursue seriously the deceptively simple question that the play suggests: how can we 'know' peace?

Within the body of Vondel's theatrical work, the allegorical play Leeuwendalers appears to occupy an anomalous position. The play is the only comedy in a long line of tragedies and is usually read as a celebration of the Treaty of Münster, which put an end to eight decades of conflict between the newly formed Dutch Republic and the Spanish Habsburgian dynasty. The treaty was part of the Peace of Westphalia, which in turn settled the bitterly violent religious struggle between Protestant and Roman Catholic nations in Central Europe that came to be known as the Thirty Years' War. By ratifying the Treaty of Münster, Spain and the Holy Roman Empire recognised de jure the Republic as a sovereign nation-state. Vondel did not wait for the official signing of the peace on 30 January 1648: he completed Leeuwendalers in 1647, when the news of a general agreement was already circulating. Chiming in with the generally jubilant mood at the prospect of peace, Vondel chose to cast his early celebration in the form of a comedy. Since the comic genre traces a shift from social upheaval to a renewed sense of harmony, it must have seemed a proper literary accompaniment to the occasion. ${ }^{11}$

${ }^{11}$ Many critics have tried to distil Vondel's political views on the Treaty of Münster from the text of Leeuwendalers. As a recent convert to Roman Catholicism and an outspoken proponent of the idea of a single, unified Dutch state, Vondel could have had many reasons to be dissatisfied with the treaty's legal affirmation of the division between the northern Republic and the Spanish Netherlands in the south. For an overview of the arguments in favour of and against such interpretations, see Anton van 
The plot of Leeuwendalers, which Vondel largely borrowed from Torquato Tasso's Aminta (1573) and Giovanni Battista Guarini's Il pastor fido (1589), can be summarised as follows. In the land of Leeuwendaal, a violent civil conflict has claimed the lives of Waerandier, ruler of the South and son of the Forest God, and Duinrijck, ruler of the North and son of the god Pan. Since the wives of both men died as a result of the fray as well, their two children are orphaned. Adelaert, the infant son of Waerandier, is entrusted to the care of Lantskroon, the new lord of the South. Vredegunt, Duinrijck's widow, has died in childbirth, but her daughter was safely delivered by the nurse Kommerijn. In her desperation to flee the war-torn countryside of Leeuwendaal, Kommerijn leaves the girl as a foundling. Vrerick, the new leader of the North, discovers her and raises the unidentified child as his own. The play starts twenty years later, when the old nurse Kommerijn returns to Leeuwendaal. She soon finds out that the bloodshed is far from over: the gods have not yet forgiven the Leeuwendalers for the deaths of their children. Each year, a youth from either the North or South, to be selected at random by the priestess, must be sacrificed to Pan in order to appease his wrath.

On the day that the fatal lot is about to be cast, the beautiful huntress Hageroos sets out to track a white deer that she hopes will serve as a replacement sacrifice. Adelaert, who is madly in love with Hageroos, follows her around to woo her, but his desperate pleas only meet with rejection: since Hageroos is an orphan of unknown parentage, she believes herself to be an unsuitable choice for the rich and noble Adelaert. Passionately lamenting his misfortune but nonetheless undeterred, Adelaert continues to chase after her. In the woods, Hageroos suddenly finds herself sexually harassed by some unknown assailant: Adelaert arrives just in time to rescue her. In spite of his heroic defence of her honour, however, Hageroos still refuses to give in to Adelaert's desire.

Meanwhile, Vrerick and Lantskroon, the lords of the North and the South, must quell the civil unrest that continues to grow as the time of the sacrifice draws near. Despite their mutual desire to cease all hostilities, they see no way to prevent or even delay the sacrificial rite. The lot is cast, and Adelaert's name comes up. Unlike his foster father, who is utterly distraught, Adelaert gladly accepts his fate: he welcomes the

Duinkerken's introduction to the play (1948). As will become clear, my own approach to Leeuwendalers is somewhat less topical. 
chance to be rid of the pain of his unrequited love. As Pan's servant, the terrifying Wild Man, is about to pierce him with arrows, Hageroos has a change of heart and suddenly jumps in front of Adelaert. Before the Wild Man has the chance to kill them both, Pan himself intervenes: Hageroos is his own flesh and blood, and no further sacrifices will be required. Kommerijn, who has slept all day after her exhausting journey back home, is able to explain Pan's words to the perplexed bystanders: she testifies that Hageroos is Duinrijck's daughter and, consequently, a granddaughter of Pan. At the close of the play, the chorus celebrates the upcoming marriage of Adelaert and Hageroos, which will finally reunite North and South and bring peace to the whole of Leeuwendaal.

Whereas Vondel's tragedies are often characterised by a strong classicist impulse, staging complex political, social, cultural, or religious problems from a variety of conflicting viewpoints, Leeuwendalers insists on presenting itself as an innocuous eulogy of peace. The play's subtitle, 'A Pastoral', already announces that its setting is bucolic: it is far removed from the city and its corruption, the elevated concerns of the courts, and the grave matters of religion and politics. In his introductory dedication to the diplomat Michel le Blon, Vondel explicitly warns those who would seek to read the play as anything more than harmless entertainment:

Anyone delving in too deep, pedantically looking for covert meanings in all the characters, verses, and words, will not find any. We have only selected and blended some paints and perfumes that would be able to serve our purpose and have thus roughly sketched, on a smaller scale, the course of war and peace so as to avoid all animosities $[\ldots]^{12}$

The rhetoric of this short passage would have us believe that Leeuwendalers is inoffensive and purely ornamental: its simple sensuous pleasantries hold no hidden depths. Nevertheless, this ostensible avowal of modesty skilfully uses the metaphors of painting and horticulture to smuggle in an intensely political pair of terms: war and peace. Although the speaker claims that the play at hand is only fanciful decoration, he already subverts his own claim by invoking this fiercely

12 'Wie hier te diep in verzinckt, en neuswijs, in alle personaedjen vaerzen en woorden, geheimenissen zoeckt, zalze'r niet visschen. Wy hebben slechts eenige verwen en geuren, die ons voornemen dienen konden, uitgezocht, en onder een gemengt, en het beloop van oorloge en vredehandel aldus in het klein ten ruighsten ontworpen, om alle hatelijckheit te schuwen [...]'. ('Dedication to Michel le Blon', 11 . 57-62); Vondel, WB, 5, p. 265. All further quotations are taken from this edition; all translations are my own (SvdL). 
debated opposition and all the politically sensitive material it touches upon. The rhetorical structure that manifests itself here, as well as in Vondel's choosing the pastoral comedy, is that of the paralipsis: while explicitly denying any interest in the profoundly political questions of war and peace, the play delves deeply into the structure of difference upon which this binary opposition is based. Instead of simply extolling the virtues of peace, Leeuwendalers demonstrates how peace can never be stably 'thought' at all. In questioning the primacy, singularity, and uniformity of this concept, Vondel's play works towards a veritable deconstruction of peace. ${ }^{13}$

Like many a binary opposition, the dichotomy of war and peace implies a hierarchical relation between the two terms. Although this relation has not been a transhistorically stable one in Western European tradition, Leeuwendalers already makes its position clear on the title page by way of its motto - pax optima rerum, or 'peace is the best of all things. Peace is the preferable state of affairs, and war amounts to an undesirable interruption of that condition. The play represents a transition from a period of violent conflict to an era of peace ushered in by the marriage of Adelaert and Hageroos. Consequently, Leeuwendalers describes a return to an originary state of harmony. In the final act, the chorus describes the bounteous rewards of that state as it celebrates the wedding: the people are enjoying the festivities, there is good cheer, the cows give milk and cream, and the barrels are brimming with real butter (1l. 2013-20). All is well that ends well. Ironically, however, it is precisely these 'virtues' of peace that were identified earlier as the roots of the conflict. When Lantskroon complains of the unforgiving attitude and blind hatred of the masses, he accuses them of ill will and ingratitude. He blames

[...] peace, which gave birth to trade, and wealth, and abundance; These in turn gave birth to haughty, headstrong, and scornful vanity: This caused the dissent, too excessive and reckless, In the midst of the feast in honour of the glory of Pan.

${ }^{13}$ Van Duinkerken suggests that we should take Vondel's advice and decline to look for 'deeper' meanings ('Introductie', p. 40). I, however, agree with Korsten, who reminds us that we are not dealing with a straightforward statement from the author here but with a textual persona instead. This 'orator' produces complex rhetorical constructions that need to be carefully analysed in their own right (Vondel belicht, pp. 19, 121; Sovereignty as Inviolability, pp. 25, 113). 
All ate, and drowned their senses in their jugs,

Until querulous words turned to blows and knives. ${ }^{14}$

Apparently, the sumptuous abundance engendered by peace also carries the seeds of discord within it. In its excesses, peace can bring forth that which supposedly is diametrically opposed to it, war. As a result, the two terms cannot be neatly distinguished from each other. Lantskroon's account of the drunken brawl at Pan's feast makes clear that the threat of violence is always embedded in the potential of peace to go beyond itself. If peace can produce its antithetical other, then the symmetry of this pair of opposed terms is broken: war is no longer inversely proportionate to peace but rather the result of a drifting apart within peace itself. Although it is possible to read Lantskroon's lines as a plea for moderation, this does not change the fact that it is always possible to reap the rewards of peace immoderately. When read in this light, the jubilant description of the joys of peace that the chorus gives at the end of the play becomes problematic: if peace can come to differ from itself, how then can it ever be guaranteed?

At this point, it is important to note that the problem of war and peace is structurally related to the question of difference and identity. Peace, after all, is commonly taken to denote harmony, unity, and stability; in order to 'make' peace, differences have to be settled or, at the very least, suspended. War, on the other hand, bears connotations of conflict, antagonism, and violent opposition. Peace unifies, and war divides - or so it appears. In the play, peace and identity are coupled for the first time as Adelaert attempts to persuade the huntress Hageroos to return his affections. Since Hageroos deems them socially incompatible, she will have none of it. When Adelaert passionately offers himself as her prey, she brusquely retorts that ' $[\mathrm{e}]$ quals are best and most peacefully paired with each other. ${ }^{15}$ Then Adelaert replies:

Not equality in wealth and standing, but equality of minds:

Equality of minds best nourishes peace and friendship:

If that is lacking, peace and friendship cannot exist;

\footnotetext{
14 '[...] pais, die neering baerde, en weelde, en overvloet; / Die baerden hoovaerdy, verwaent, en trots, en smadigh: / Zoo quam de tweedraght voort, te byster en baldadigh, / In't midden van het feest, geviert ten roem van Pan. / Men at 'er, en verdronck de zinnen in de kan, / Zoo dat men tot gevecht en messen quam, van woorden.' (ll. 644-49)

15 'Gelijckheit paert zich best en vreedzaem by malkandere' (1. 266).
} 
Without them, I value neither wealth nor blood and birth.

It is peace and friendship that keep the world within bounds. ${ }^{16}$

The speech continues with an extensive image of nature as a series of amorous couples that all act according to 'the music of like minds' $:{ }^{17}$ the surf kisses the beach, the sea embraces the dunes, pigeons coo together, ivy lovingly wraps itself around the bark of a tree, and harts and hinds tenderly lick each other. Adelaert can only pray that Hageroos will one day emulate nature as well.

The word 'peace' does not refer to armistices, truces, and other pacts of non-violence between states here. Seeing as Adelaert explicitly uses music as a metaphor, 'peace' should probably be understood as 'harmony': what is evoked is the idea that nature is a properly orchestrated whole. All internal difference in nature is overcome by the single amorous disposition that all its elements share. This identity of minds, Adelaert claims, even countermands all social stratification. Without the homogenising impulses of peace and friendship, distinctions based on lineage and wealth lose their value and the world will spin out of bounds. What Adelaert accuses Hageroos of, in other words, is that she disrupts natural harmony. Her obstinate incongruence causes overcast skies and makes him wither away '[1]ike faded green, or grass on walls and tiles. ${ }^{18}$

For Hageroos, however, who sees identity and difference as cultural rather than natural categories, 'peace' can only exist between class equals. As an insignificant girl of unknown parentage, she is all too aware of the severe impact that difference can have in the social sphere. Whereas Adelaert hears the 'music of like minds' and sees the world as a harmonious concordance, she only registers a monotonous whining (11. 294-95) that glosses over a very real abyss between them. Adelaert's utopian fantasy of peace must repress this abyss in order to sustain itself, and in so doing commits the violence of indifference upon those on the other side of the class divide. By adamantly rejecting Adelaert, Hageroos exposes the idea that 'peace and friendship' can bridge any gap as a sentimental and dangerously oblivious myth.

\footnotetext{
16 'Gelijckheit niet van goet en staet, maer van gemoedt: / Gelijckheit van gemoedt best vrede en vrientschap voedt: / Waer deze ontbreekt, moet vrede en vrientschap ook ontbreken; / Waer buiten ick noch goet, noch bloet, noch afkomst reken. / De vrede en vrientschap houdt de weerelt in den bant'. (ll. 267-71)

17 '[... 't muzijck van een' gelijcken aert' (1. 275).

18 'Gelijck vertreden groen, of gras op muur, en pannen' (1. 289).
} 
In its guise as a 'natural' condition of harmonious identity, peace is a highly ideological concept that cannot tolerate internal difference. The disruptive potential of social inequality must be suppressed if the term 'peace' is to function at all. In a similar fashion, political peace - a state of non-violence guarded by certain institutions - must project the volatility of self-excess onto 'war', its binary opposite, in order to maintain the illusion that a neat separation between the two concepts is possible at all. In Leeuwendalers, these two convergent concepts of peace - the ideology of a harmonious world order and the pact of non-violence meet in the prospective marriage of Adelaert and Hageroos. At the crucial moment when Pan, in a sudden act of divine intervention, rescues them both from the Wild Man's murderous arrows, he proclaims:

Let the marriage of a pair sprung from the Gods of the Fields Unite Leeuwendaal after so much discord and sorrow. ${ }^{19}$

Pan makes clear that the renewed unification of Leeuwendaal is inextricably bound to this particular marriage. In retrospect, then, the peace that constitutes this play's happy ending is completely dependent on the question of whether or not Hageroos yields to Adelaert. This goes a long way to explain the youth's eager persistence: within the structure of the play, his wooing is a crucial political project. The fate of an entire nation depends on it. Tellingly - but, from a historical perspective, unsurprisingly - the object of this project is a female body.

In his book Vondel belicht (Sovereignty as Inviolability), Korsten has argued that Adelaert's role is an ambiguous one: although he rescues Hageroos from a mysterious assailant, the text also suggests that Adelaert and this would-be rapist can be conflated. Adelaert is repeatedly compared to a dog chasing after a hare, his behaviour is almost animalistic, and, like the rapist, he is mad with desire for Hageroos. Consequently, Adelaert can simultaneously be seen as a protector and an aggressor. ${ }^{20}$ In both roles, however, the crucial issue is sexual possession. This observation is further sustained by the fact that Adelaert's texts are rife with erotic innuendo. A few examples will suffice:

If only fortune would turn me into a dog,

A partridge, or a fast hare, I would fly into your mouth:

19 'Het huwelijck van een paer, geteelt uit Ackergoden, / Vereenigh' Leeuwendael, na zoo veel twist en smert.' (ll. 1865-66).

${ }^{20}$ Korsten, Vondel belicht, pp. 129-29; Sovereignty as Inviolabiltiy, pp. 114-19. 
I'd want to give you all that's mine and would humbly offer you My body, my soul, and my life as bounty for you to plunder. ${ }^{21}$

The maid relieves the cattle's dugs twice a day, When they are crammed with milk and cream: And I, though I constantly complain of my misery to you, Am never relieved of the yoke of lovers' cares. ${ }^{22}$

My salvation would be complete if my morning star, My sweet Hageroos, could be present here, And would deign to catch my spirit with her mouth When life's essence departs through the heart's wound, Still red and warm with blood - blood that I will gladly Commend to her, if I were to die in her favour. ${ }^{23}$

If one were to put it anachronistically, these passages could be called masochistic, racy, and morbid respectively. In all of them, Hageroos's body is turned into an object to which Adelaert has to gain 'access'. Whether this is to be accomplished by a fantasy of ingestion, an appeal to a woman's duty to offer 'relief', or an attempt at ghostly possession, he will in any case become one with her. Even when Adelaert is about to die, his overwhelming desire to claim the body of his love interest is the first and foremost thing on his mind. As a final request, he asks his foster father to make sure that Hageroos and he will be interred in the same grave. Should she die a virgin, her pure corpse can be used to consecrate his burial place (11. 1758-61). The inscription he would like to see on their tombstone, however, proves that his own intentions for that corpse are anything but pure: 'Here slumbers Hageroos, lying next to Adelaert: / Her cold bones can still ignite his ashes. ${ }^{24}$ Adelaert's desire to physically possess Hageroos's body persists even beyond death.

In Leeuwendalers, the female body is constantly in danger of being ravished, utilised, or overtaken by men. Even their supposed concerns for its safety should in fact be read as silent affirmations of the female

21 'Veranderde 't geluck my heden in een' hont, / Patrijs, of snellen haes, ick vloogh $\mathrm{u}$ in den mont: / Ick woude $\mathrm{u}$ al het mijne, en lijf en ziel en leven / Ootmoedigh tot een' buit en roof ten beste geven.' (11. 259-62)

22 'De meit ontlast het vee zijn uiers, stijf gespannen / Van zoete melck en room, wel tweemael alle daegh: / En ick, die, dagh op dagh, u mijn ellende klaegh, / Wort nimmermeer ontlast van 't juck der minnezorgen.' (ll. 290-93)

${ }^{23}$ 'Ick zaegh mijn heil voltoit, zoo nu mijn morgenstarre, / Mijn lieve Hageroos hier tegenwoordigh stont, / En my gewaerdighde mijn' geest met haren mont / Te vangen, als de ziel ter hartwonde uit zal vaeren, / Noch root en warm van bloet, van bloet, het welck ick gaeren / Ten beste geve, indien ick in haer gunste sterf.' (ll. 1808-13)

24 'Hier sluimert Hageroos, by Adelaert gezoncken: / Haer koudt gebeente kan zijn assche noch ontvoncken' (1l. 1763-64). 
body's vulnerability. When Hageroos explains how she narrowly escaped from the clutches of a rapist, the chorus replies that such a thing is bound to happen to women who roam the woods '[a]lone and unaccompanied' ('Alleen, en onverzelt', 1. 893). What the chorus implicitly chides Hageroos for here is her earlier refusal of male protection: in order not to become a possible target for any man's wild desires, she should have given in to those of a single man. To yield means being protected, to resist means being at risk. In a scene that similarly revolves around the idea of the female body being an object created for the use of men, Heereman, Lantskroon's steward, has devised a scheme to save Adelaert from his grisly fate. He asks Hageroos to don a beautiful dress and 'enthral' the executioner, the fearsome Wild Man, with wine and music. Hageroos, however, realises full well what 'enthralling' means in this context. 'I have only just escaped from the abuser', she replies, '[a]nd do not want to betray myself so recklessly. ${ }^{25}$ Heereman's ruse amounts to using Hageroos's sexual allure as a trap; in his view, the possible loss of honour - the devaluation of her maidenly status - is a small price to pay if there is a chance to rescue Adelaert. He is quite willing to accept the danger of rape and proposes to 'trade' Hageroos's bodily integrity for Adelaert's life. This cynical gesture once more bespeaks a utilitarian view of the female body: it is a tool that can be employed in the political dealings of men, a prized object that has to be acquired or defended, and a vessel for male fantasies of sexual possession.

Within a world that invests the female body with such problematic and potentially destructive meanings, the marriage that Pan finally ordains might seem to be the most blissful solution. Yet, upon closer inspection, it turns out that the supposed nuptial bliss and subsequent peace in fact rely upon an act of silencing. When Hageroos intercedes at the sacrificial ritual and challenges the Wild Man to kill her first, she explains her sudden readiness to die to Adelaert: 'Your devotion obliged me: now I will offer up my body / And take your place. ${ }^{26}$ Tellingly, she does not give her body to Adelaert here: just as Adelaert prevented her from being raped, Hageroos now shields him from a different type of violent penetration. She is willing to give her life to repay him, but nowhere does she explicitly concede to Adelaert's will. From the

25 '[I]ck ben den schender pas ontgaen, / En wil zoo reuckeloos my zelve niet verraên' (1l. 1465-66).

${ }_{26}$ 'Uw trouw verplichte my: nu geef ick 't lijf ten beste, / En trede in uwe plaets' (ll. 1836-67). 
moment that Pan intervenes and 'pronounces' the wedding, Hageroos has no more lines. The stage is left to the male authorities, who can conclude their business: Lantskroon appoints himself 'Father of Peace' ('Vredevader', 1. 1984), plans the future political constellation of Leeuwendaal, and orders his subjects to give thanks to their divine saviour. Hageroos's unwavering resistance to male political desires, her adamant refusal to conform to an ideology of peace that would seek to erase difference, and her freedom to dispose of her body as she sees fit are all ignored in the end: when Pan resolves the differences between North and South by a display of divine force, he also smothers the play's one dissenting voice.

It may be surprising that Pan, the one who grants peace, simultaneously functions as an agent that curbs discordant elements here. However, the ambiguity of this particular character has been the subject of some debate. Since Leeuwendalers is an allegory and Pan is the only god who is continually being invoked, he is usually taken to be a representation of the one true God. In his dedication to Le Blon, Vondel takes ample time to justify his choice: since 'Pan', in Greek, means 'all', he is the most appropriate figure to refer to the divine origin of everything in nature. Apart from being a particular pastoral deity, then, Pan also prefigures the Christian God by way of his transcendental aspects. As stated by Van Duinkerken, Vondel's use of Pan skilfully balances two equally undesirable alternatives: the unabashed portrayal of heathen polytheism on the one hand and a direct representation of the conflicts of a deeply divided Christian world on the other. ${ }^{27}$ W.A.P. Smit has further endorsed the notion that Vondel's Pan suggests the one true God without actually being Him. In that way, or so Smit claims, the didactic message that the Peace of Münster was an act of divine grace could be conveyed without abandoning the inoffensive guise of the Arcadian fiction. ${ }^{28}$ What both Smit and Van Duinkerken propose, in other words, is to separate Pan's pagan traits from his properly monotheistic aspects and only read the figure allegorically when its presentation does not conflict with orthodox Christianity. This proposition is profoundly ideological, since it entails interpreting selectively in order to achieve a certain sense of hermeneutic unity: contradictory elements within a single character are explained away as simple reminders of the play's fictionality.

27 'Introductie', p. 46.

${ }^{28}$ Smit, Van Pascha tot Noah, 1, pp. 456-58. 
Korsten provides an elegant solution to this interpretive conundrum by arguing that the play juxtaposes pagan polytheism and Christian monotheism as sovereign religious cultures within the same body: instead of being supplanted by Christianity, classical traditions are activated and start to create a complex interdiscursive field of meanings. ${ }^{29}$ Korsten's subsequent suggestion that Pan presents a full-fledged alternative to the Christian logic of the necessary sacrifice, however, is somewhat more problematic. It may be so that this highly ambiguous, semi-bestial classical deity cannot be stably translated into the one true God, but neither can he simply serve as the latter's positive antithesis. Korsten, however, seems to suggest as much when he distributes the binary pairs reasonable/unreasonable, peacegiver/warmonger, and compassion/ruthlessness between them. Although Pan eventually puts a stop to the civil war, this momentary display of reasonability is actually an integral part of the theatrics of absolute power. Precisely because it is an act of grace, Pan's intervention is also an affirmation of divine omnipotence. In 'giving' peace, he simultaneously quells Hageroos's resistance to homogenisation, forcibly expunges difference, and reaffirms his sovereign right to grant (or withhold) his bounty as he pleases. In doing so, he does not become a real alternative to divinely authorised violence but a different type of potentate instead.

To further illustrate my point, I will return to the third act. Hageroos has just informed the chorus of the attempted rape and has left to worship Pan in the chapel. Adelaert, who has captured and released her mysterious assailant, is now secretly spying on her from behind a column. At this point, the chorus observes that no one can seem to love a woman without displaying beastly behaviour: all love-smitten men grunt like boars or howl like dogs. Then, the chorus suddenly makes mention of some crucial myths concerning Pan:

But they say that Pan sought his diversions in the East, Near a stream, and that he chased them through the reeds:

That he, to impregnate the ancient moon by night,

Disguised himself as a goat, yes, even had to become a goat;

If one is allowed to say so, since it is seen or heard by no one..$^{30}$

${ }^{29}$ Korsten, Vondel belicht, pp. 141-42; Sovereignty as Inviolability, pp. 129-30.

30 'Al pratenze dat Pan, in Oostlant, bij een' vliet, / Zijn mallicheden zocht, en naerpeurde in het riet: / Dat hy, om doude maen by avont te begorden, / Ging mommen, als een bock, ja zelf een bock most worden; / Indien men 't zeggen magh, daer 't niemant ziet, en hoort.' (ll. 1053-57) 
Like Adelaert, Pan can apparently fall prey to his lusts and quite literally become a beast. Unlike Adelaert, however, he does not transfer his wild desires to the heated discourse of fantasy: as a brutish but powerful god, he simply takes what he wants. In a footnote, Smit euphemistically calls the mythical narratives that are referred to in these lines 'erotic adventures' ${ }^{31}$ - they have no other purpose than reaffirming that Pan is an Arcadian fiction that can never be totally converted into a symbol for God. In the case of a play that is charged with male sexual desire, that features at least one attempted rape, and in which the political fate of a nation eventually depends on whether a young woman yields her body, such a reading falls painfully short. The implication that the peacegiver, the one who is responsible for the long-awaited comic ending, is also a rapist changes the entire play. If Pan has the power to freely indulge his animal impulses, hounding and impregnating nymphs and goddesses - unseen, unheard, and, consequently, unchecked - the peace that he proclaims is dangerously dependent upon his whims. In fact, the chorus's reference to the rape narratives makes clear that the entire plot centring on Hageroos is structured in a disturbingly similar way: a man can hardly contain his desire for a woman who refuses him, after which she is forced into submission and silenced by a superior power. When Pan simply ordains the marriage, exploits his granddaughter's body for political reasons, and suppresses her resistance to male domination, his actions metaphorically constitute rape.

In Leeuwendalers, peace is anything but peaceful. The continual blazoning of the word throughout the play is an attempt to veil a different kind of violence. Stemming from internal repression, this aggression is systematically directed at the levelling of all differences that the ideology of harmony cannot tolerate. Social inequality is ignored, female dissent is overruled, and past injustices are erased by decree. It is this tension that is epitomised in the verb 'to pacify', which bears the connotation of 'restoring the peace' but also of 'violently subjugating'. By entwining the course of war and peace with the narrative structure of rape, Leeuwendalers deeply unsettles the seemingly unproblematic ideology of a harmonious unity and deconstructs its claim to superiority. The play suggests that peace, a harmonious state of non-violence, can only come about by violently suppressing self-difference and otherness.

\footnotetext{
${ }^{31}$ Smit, Van Pascha tot Noah, 1, p. 458, n. 3.
} 
In his Adieu to Emmanuel Levinas, Derrida contrasts Kant's use of the concept of peace to that of his late friend. He concludes that Kantian peace is a condition that must be instituted by nation-states in order to ward off a return to the natural state of war. As a promise, however, it indefinitely and inevitably retain[s] within it a trace of the violent nature with which it is supposed to break. ${ }^{32}$ This threat permanently contaminates even the most sincere promise of peace: after all, there is always the potential for renewed hostility. In Leeuwendalers, Pan's sovereign position allows him to violate his self-proclaimed peace whenever he would see fit. Since his track record includes human sacrifice and rape, the play does not end on an unequivocally comic note. The very institution of Pan's peace is at the same time a threat of further violence: what an absolute power gives it can just as easily withdraw. It is this notion of a whimsical and violent divine sovereignty that Lantskroon questions when he asks: 'Is a deity not able to relinquish her rights?'- and it is also this notion that Vrerick docilely affirms: 'The master does not allow the servant to reproach him.'. ${ }^{33}$

The opening question of this essay was whether deconstruction, a modern theoretical approach, would be absolutely incompatible with traditional philology. On one level, the answer would have to be that it is. A deconstructionist cannot subscribe to the notion that a text can be reconstructed according to its author's original intentions. The slippery system of language itself would make that enterprise futile. On a different level, however, the deconstructionist is in fact the ultimate philologist: he continues to pursue the text until its fabric of signification becomes too intricate to perceive. As Barbara Johnson has argued, the humanist critic stops reading when the text 'stops saying what it ought to have said' - he stops, in other words, when his interpretation fits into a familiar (historical) frame. ${ }^{34}$ The deconstructionist, however, can allow mutually exclusive readings to exist simultaneously, thereby allowing the past to speak with many voices.

In her review of Vondel belicht, Schenkeveld indicts Korsten for turning the internal dialogues of Vondel's plays into a monologue. The orthodox Christian Vondel, who in the end accepts the human suffering that is part and parcel of God's inscrutable purposes, has been

\footnotetext{
32 Derrida, Adieu to Emmanuel Levinas, p. 89.

33 'Vermagh een Godtheit niet te scheiden van haer recht?', (1. 683); 'De meester laet zich niet bedillen van den knecht' (1. 684).

${ }^{34}$ Johnson, 'Teaching Deconstructively', p. 140.
} 
filtered out and is replaced by a suspiciously modern Vondel - a Vondel who rejects religiously motivated violence and emphasises the sovereign potential that is intrinsic to human society itself. ${ }^{35}$ Bearing in mind my own experiences in the case of Leeuwendalers, however, I would put it somewhat differently: Korsten's questioning, passionate, life-affirming figure is placed next to the ultimately submissive believer. The polyphonous ingenuity of Vondel's verses makes it maddeningly impossible for the reader to opt safely for either interpretation. It is this aporia that enables us to fully appreciate the impact of Vondel's theatrical works, without either locking them in the past or forcibly jerking them into our postmodern age. In the end, only a reading that allows a historical text its self-contradictions, suspensions, subversions, and uncertainties can do justice to both its historicity and its existence in the present.

${ }^{35}$ Schenkeveld-van der Dussen, 'Vondel geïnterpreteerd', p. 140 et passim. 